Adamovych O. O., Yashchenko A. M. Analysis of the frequency of pathologies of the cervical spine in adolescents according to computed tomography. Journal of Education, Health and Sport. 2021;11(08):457-462. eISSN 2391-8306. DOI http://dx.doi.org/10.12775/JEHS.2021.11.08.051

https://apcz.umk.pl/JEHS/article/view/JEHS.2021.11.08.051

https://zenodo.org/record/5550803

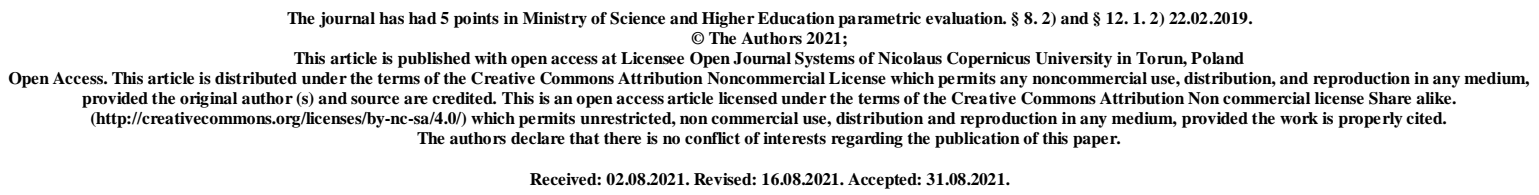

UDK: 611.93:611.711]:616 - 073:519.222

\title{
ANALYSIS OF THE FREQUENCY OF PATHOLOGIES OF THE CERVICAL SPINE IN ADOLESCENTS ACCORDING TO COMPUTED TOMOGRAPHY
}

\author{
O. O. Adamovych, A. M. Yashchenko
}

\section{Danylo Halytsky Lviv National Medical University}

O. O. Adamovych - Assistant department, Department of Normal Anatomy, Lviv, Ukraine, Danylo Halytsky Lviv National Medical University, Lviv, Ukraine.

https://orcid.org/ 0000-0001-5729-1118

A. M. Yashchenko - MD, Professor, Department of Histology, Cytology and Embryology, Danylo Halytsky Lviv National Medical University, Lviv, Ukraine.

https://orcid.org/0000-0002-8422-5834

\section{Abstract}

Spinal pathologies today occupy a leading position in the rankings of diseases with a high degree of disability of patients, translating the problem into the category of medical and social. Cervical lesions are one of the most common manifestations of spinal pathology, and cervical osteochondrosis ranks second after lumbar. Literature sources indicate that today spinal pathologies have a pronounced tendency to rejuvenate. The aim of our study was to determine the frequency of pathological lesions of the cervical spine among adolescents in a randomized sample according to computed tomography. 100 series of anonymized computed tomograms of young people (18-21 years old) were processed. The examination was performed on the TSX-101A Aquilion 16. According to the analysis, only $22 \%$ of the examined young people do not have pathological changes in the study area. Changes in 
intervertebral discs in the form of protrusions of different localization were found in $51 \%$ of the examined persons, in $23 \%$ - intervertebral hernias. The high frequency of pathological lesions of the cervical spine indicates the need to identify the causes of their occurrence, as well as the development and application of effective preventive measures.

\section{Key words: cervical spine; adolescence; computed tomography.}

\section{Introduction}

Pathologies of the spine today occupy a leading position in the rankings of diseases that have a high degree of disability of patients, translating the problem into the category of medical and social [1-4]. The most common diseases of the spine include its pathological curves, traumatic injuries, osteochondrosis, intervertebral hernias and protrusions. Among the causes of spinal pathologies in addition to heredity and trauma, various authors call hypodynamia, prolonged static position, inadequate physical activity, improper workplace organization, chronic fatigue and stress, sleep and eating disorders, deficiency or excess weight $[1,2,3,5]$. The cervical spine is the most labile and, at the same time, the most vulnerable to external factors and has a pronounced ability to quickly adjust under their action [5-8]. O.E. Marchenko, B.A. Nevsky [9] emphasize that cervical lesions are one of the most common manifestations of spinal pathology, and cervical osteochondrosis ranks second after lumbar.

Literature sources indicate that today spinal pathologies have a pronounced tendency to rejuvenate [3-5, 10]. Drozdova KV, Bashavets NA [4] emphasize the problem of juvenile osteochondrosis, which can develop in 5-6-year-old children, but most often affects the spine of 10-12-year-olds against the background of hormonal changes in the body. Osteochondrosis is asymptomatic mainly in children, adolescents and adolescents [4] and its symptoms can be detected only by the results of screening examinations, in particular - computed tomography.

The aim of our study was to determine the frequency of pathological lesions of the cervical spine among adolescents in a randomized sample according to computed tomography.

Material and research methods. In the course of the work we processed 100 series of anonymized computer tomograms of adolescents ( 50 boys and 50 girls), who under various indications or for screening purposes were examined at the medical center "ABSolyut MED" (Lviv) (Fig. 1). The selection criterion was age (18 - 21 years). The examination was performed on a TSX-101A Aquilion 16. 


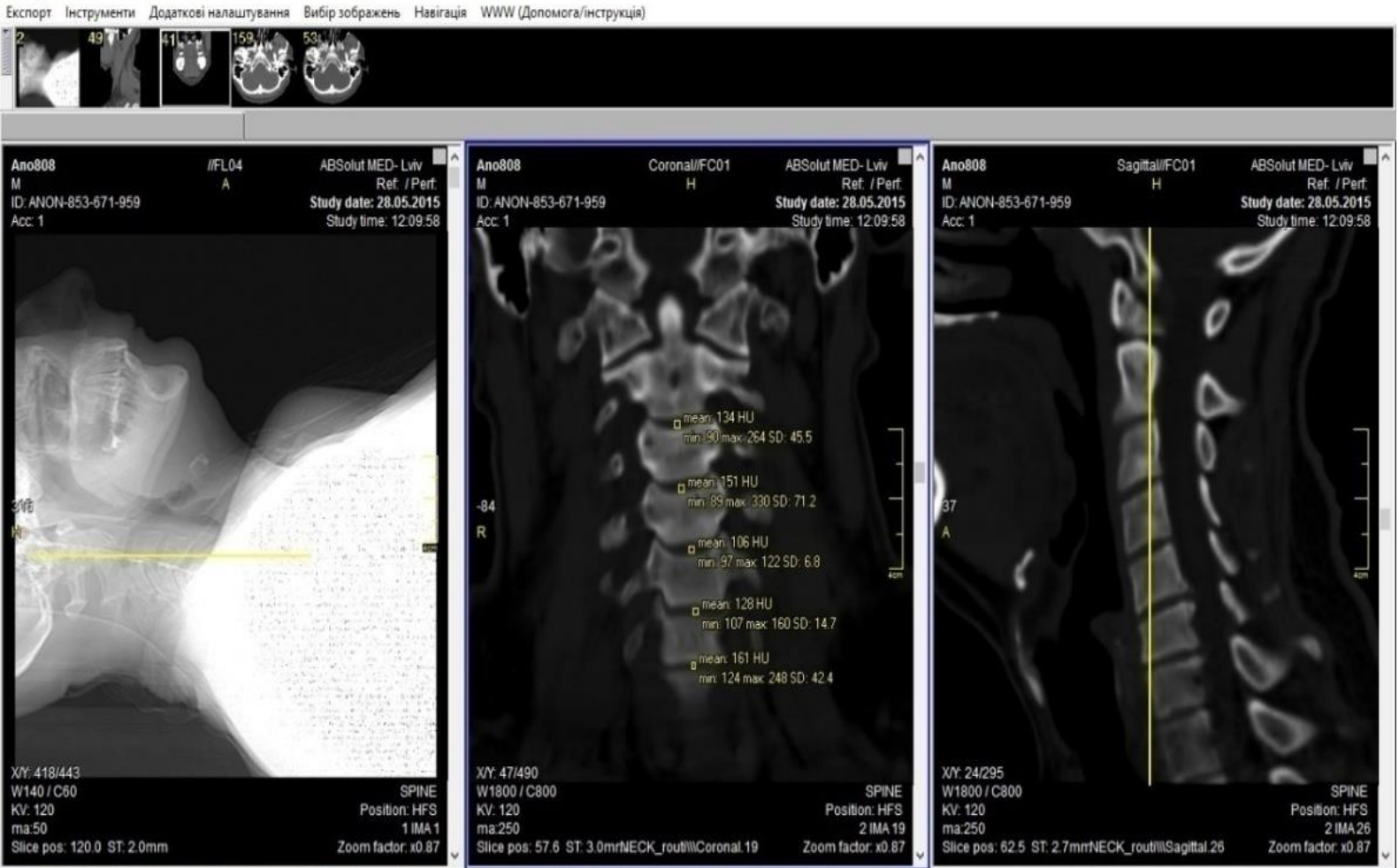

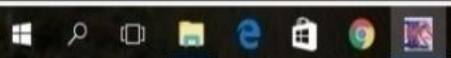

Fig. 1. Computed tomography of the cervical spine of a 19-year-old boy

\section{Research results}

As a result of processing 100 series of computed tomograms of the cervical spine of adolescents, more than half of the subjects were diagnosed with protrusions of various shapes and locations ( $51 \%$ of subjects, including 25 boys (50\% of all examined boys) and 26 girls Only protrusion was diagnosed in 9 boys (4.5\%) and 8 girls (4\%), and in all other cases, 16 boys and 18 girls, protrusion was part of the combined lesion: protrusion and trauma (6 people), protrusion, trauma and scoliosis (3 people), protrusion and scoliosis (12 people), protrusion, scoliosis and intervertebral hernia (5 people), protrusion and intervertebral hernia (5 people).

Scoliosis of the cervical spine was found in $37 \%$ of the examined persons. Among those diagnosed with scoliosis, 16 boys (32\% of all examined boys) and 21 girls ( $42 \%$ of all examined girls). Scoliosis as an isolated pathology of the cervical spine was detected in only 5 people ( 1 boy and 4 girls), and as part of combined pathologies - in 32 people (15 boys and 17 girls). The most common combination of scoliosis with protrusion (12 people). The combination of scoliosis with trauma was found in 6 people; scoliosis with protrusion and 
between the vertebral hernia in 5 people; scoliosis with hernia in 3 people, and a combination of scoliosis with protrusion, hernia and trauma in 3 more people.

Injuries of the cervical spine were diagnosed in $25 \%$ of the examined, including 15 boys (30\% of all examined boys) and 10 girls (20\% of all examined girls). Trauma on the background of physiologically formed cervical spine without additional identified pathologies was diagnosed in only 6 people; trauma on the background of scoliosis - in 6 people, trauma on the background of protrusions - in 6 more people; trauma on the background of scoliosis and protrusions - in 3 people; trauma on the background of detected intervertebral hernias - in 1 person and trauma on the background of scoliosis with detected protrusions and intervertebral hernias - in 3 people.

$23 \%$ of all subjects (11 boys and 12 girls) were diagnosed with intervertebral hernias. In this case, hernias as an isolated pathology of the cervical spine were found in only 6 people; in combination with an injury - at 1 person; in combination with protrusion - in 5 people; in combination with trauma and protrusion on the background of scoliosis - in 3 people; on the background of scoliosis only - in 3 people and on the background of scoliosis in combination with protrusion in 5 more people.

The smallest group among all examined were persons with a physiologically formed spine, in which the examination did not reveal any pathological changes in the cervical spine. This group included $22 \%$ of the surveyed, including 12 boys ( $24 \%$ of all surveyed boys) and 10 girls (20\% of all surveyed girls).

The results of the study showed that changes in the intervertebral discs in the form of protrusions of different localization are now detected by CT examination of more than half of adolescents included in the randomized sample, the criterion for the formation of which were age limits. The high frequency of protrusions, as well as intervertebral hernias, found in our study in adolescents, coincides with the data of the scientific literature on the rejuvenation of spinal pathologies $[3-5,10]$. Taking into account their often asymptomatic course, we believe that the priority tasks of modern vertebrology today should include the prevention of juvenile osteochondrosis, as well as scoliosis, which is found in $37 \%$ of respondents.

\section{Conclusions}

1. According to the analysis of a random sample of series of computed tomograms of the cervical spine of adolescents, only $22 \%$ of subjects do not have pathological changes in the study area.

2. Changes in intervertebral discs in the form of protrusions of different localization were found in $51 \%$ of the examined persons, in $23 \%$ - intervertebral hernias. 
3. The high frequency of pathological lesions of the cervical spine indicates the need to identify the causes of their occurrence, as well as the development and application of effective preventive measures.

\section{References}

1. Plakhtiy P, Halachenko O, Pikush V. Profilaktyka i likuvannya osteokhondrozu khrebta. Kam'yanets'-Podip's'kyy : PP Buynyts'kyy OA. 2011; 112. [Ukrainia]

2. Orlov MA, Dorfman IP, Orlova YEA. Osteokhondroz pozvonochnika - spornyye i nereshonnyye voprosy diagnostiki, lecheniya, reabilitatsii. RMZH. 2015; 82: 1669-1672. [Rusian]

3. Kuts-Burdeyna OO, Rudyy YUY, Marchuk OV, Luchenko YAV. Faktorna struktura fizychnoyi ta funktsional'noyi pidhotovlenosti studentiv z porushennyam postavy. Pain medicine. 2018; 3(2/1): 234-242. [Ukrainia]

4. Drozdova KV, Bashavets' NA. Likuval'na fizychna kul'tura u kompleksi terapiyi yuvenil'noho osteokhondrozu. Innovatsiyna pedahohika. 2020; 27: 106-111. [Ukrainia]

5. Adamovich YEA, Krivko YUYA, Magl'ovanyy AV. Analiz chastoty vstrechayemosti patologicheskikh izgibov pozvonochnika sredi lits yunosheskogo vozrasta. V: Materialy VIÍ mezhdunarodnoy konferentsii Sovremennyye aspekty reabilitatsii v meditsine. Yerevan. 2015: 13-15. [Rusian]

6. Pedachenko YEG, Khizhnyak MV, Pedachenko YUYe, Tanasiychuk AF, Kramarenko VA, Furman AN. Taktika khirurgicheskogo lecheniya bol'nykh po povodu mnozhestvennykh gryzh mezhpozvonkovykh diskov sheynogo otdela pozvonochnika. Klíníchna khírurgíya. 2017;10(96):33-5. [Rusian]

7. Kolisnyk PF, Liskov YAP, Kolisnyk SP, Kolisnyk VI, Honcharova NS, Dolynna OV. Zv"yazok mizh pokaznykamy vertebrobazylyarnoho krovotoku ta stabilometriyi u patsiyentiv $\mathrm{z}$ peryferychnym holovokruzhinnyam i deheneratyvnymy zminamy shyynoho viddilu khrebta. Pain medicine.2018; 3( 2/1):340-345. [Ukrainia]

8. Kolisnyk PF, Dolynna OV, Baranova IV, Honcharova NS, Kolisnyk SP, Rudyy YUY, Liskov YAP. Postural'nyy balans u patsiyentiv $\mathrm{z}$ hipertonichnoyu khvoroboyu ta deformuyuchymy dorsopatiyamy shyynoho viddilu khrebta. Pain medicine.2018; 3( 2/1):340345. [Ukrainia]

9. Marchenko OYE, Nevs'kyy VA. Dosvid vykorystannya keydzhiv dlya operatyvnoho likuvannya patolohiyi shyynoho viddilu khrebta. Medytsyna transportu Ukrayiny. 2009; 2: 26-29. [Ukrainia] 
10. Maydannyk VH, Mityuryayeva IO, Hnyloskurenko HV, Kukhta NM, Kulyk VO, Molochek NV. Kryteriyi dyferentsiyovanoho pidkhodu do likuvannya ditey, khvorykh na paroksyzmal'nu vehetatyvnu nedostatnist' na tli patolohiyi shyynoho viddilu khrebta. Bukovyns'kyy medychnyy visnyk. 2016; 20((1)77): 65-71. [Ukrainia] 